\title{
What Exactly Is Racial Diversity?
}

\author{
Silence at Boalt Hall: \\ The Dismantling of Affirmative Action
}

\author{
By Andrea Guerrero
}

Berkeley: University of California Press, 2002. Pp. 247. \$19.95 Paperback.

Reviewed by Devon W. Carbado $†$ \& Mitu Gulati††

\section{INTRODUCTION}

Andrea Guerrero's Silence at Boalt Hall: The Dismantling of Affirmative Action ("Silence at Boalt Hall") is the story of the rise and fall of affirmative action at Boalt Hall, the law school of the University of California at Berkeley ("Boalt Hall" or "Boalt"). According to Guerrero, her book is neither a "general history of affirmative action" nor a "rigorous study of admissions criteria" (p. xiii). Guerrero's purpose in examining affirmative action at Boalt Hall is to "ground" the theoretical aspects of the affirmative action debate in the context of a real institution (p. xiii). The story Guerrero tells is nuanced and rich in detail, successfully giving the reader the sense of being there. Further, Guerrero's policy analysis, though not as developed as one might like, is illuminating. With the Supreme Court poised to decide the future of affirmative action in two cases this term, ${ }^{1}$ Guerrero's book anticipated a discussion that is now at the forefront

Copyright $\bigcirc 2003$ California Law Review, Inc. California Law Review, Inc. (CLR) is a California nonprofit corporation. CLR and the authors arc solely responsible for the content of their publications.

$\dagger$ Professor of Law \& Director of the Critical Race Studics Concentration, University of California, Los Angeles.

+ Professor of Law, Georgetown University. This Review Essay benefited from comments and conversations with Kimberlé Crenshaw and Cheryl Harris. Jonathan Phillips and Elizabeth Barros provided research and cditorial assistance.

1. The cases before the Court are Grutter v. Bollinger, 288 F.3d 732 (6th Cir. 2002) (en banc), cert. granted, I23 S. Ct. 6I7 (Dec. 2, 2002), and Gratz v. Bollinger, 277 F.3d 803 (6th Cir. 2001), cert. granted, 123 S. Ct. 602 (Dec. 2, 2002). 
of the national policy debate. The experiences of schools in postaffirmative action states, such as Texas, Florida, and California, will likely play a key role in shaping the Court's determination. Guerrero's book is one of a handful of sources we have about those experiences.

However, Silence at Boalt Hall suffers from a drawback common in the affirmative action literature. While the book is fundamentally about the dismantling of racial diversity, it does not define what it means by the term "diversity." Nor does the book provide a clear sense of the precise functions of diversity. Without an understanding of what is meant by "diversity" and an appreciation of its social benefits, assessing the cost of dismantling diversity is difficult. More immediately, understanding the meaning and functions of diversity is crucial to the affirmative action cases before the Court this term. Current affirmative action policies of universities in the United States almost all derive from Justice Powell's opinion in University of California $v$. Bakke, in which he said that race may serve as one factor in university admissions practices aimed at the "attainment of a diverse student body." ${ }^{3}$ The pursuit of racial diversity, in other words, could be a compelling state interest. ${ }^{4}$ Justice Powell, however, left incomplete what he meant by diversity and why he believed diversity was so important. ${ }^{5}$ We do not think that the reason the diversity rationale is underdeveloped in Powell's opinion is because the concept is sufficiently clear as to not warrant full explication. We do not believe, in other words, that we as a society simply know diversity when we see it. ${ }^{6}$

Nor do the benefits of diversity go without saying. ${ }^{7}$ They must be theorized and demonstrated. This project is all the more important given that, if the Supreme Court is to uphold affirmative action this term, presumably it will do so because of the value of racial diversity in the educational process. And to do that (or not), the Court will have to figure out not only what racial diversity is but also what it does. With Silence at Boalt Hall as a backdrop, this Review Essay attempts to answer these questions.

After commenting on the contributions Guerrero's book makes to the affirmative action debate, we supplement it with a taxonomy for diversity.

2. In this Review Essay, we use the term "divcrsity" as a shorthand interchangeable with the more specific term "racial diversity." We of course recognize that the term "diversity" applies much more broadly.

3. 438 U.S. 265,311 (1978).

4. A govcrnmental use of a racial classification "must serve a compclling governmental interest, and must be narrowly tailored to further the interest." Adarand Constructors, Inc. v. Pena, 515 U.S. 200,235 (1995).

5. What Justice Powell did suggest was that First Amendment interests supported raceconscious practices to create racially diverse student communities so as to promote "atmosphere[s] of "speculation, experiment and creation."' Bakke, 438 U.S. at 312.

6. Cf. Jacobellis v. Ohio, 378 U.S. 184, 197 (1964) (Stewart, J., concurring) (stating famously about hard-core pornography that "I know it when 1 see it").

7. See Hopwood v. Tcxas, 78 F.3d 932 (5th Cir. 1996), cert. denied, 518 U.S. 1033 (1996) (holding that diversity is not a compelling justification for affirmative action). 
We posit seven different ways of conceptualizing the utility of diversity: diversity in the context of (1) inclusion; (2) social meaning; (3) citizenship; (4) belonging; (5) colorblindness; (6) speech; and (7) institutional culture. Each conception relates to the othcr, and some share the same underlying assumptions, but we discuss them separately for reasons of clarity. We hope this framework will cause the concept of diversity to have more political and doctrinal traction in the current debate.

Before proceeding, we should disclose that our particular perspective is informed by our time as faculty members at Boalt's sister institution, UCLA Law School. The two of us were hired at UCLA in 1997, the year immediately following the passage of Proposition 209. We experienced firsthand the effects of UCLA moving from one of the most racially diverse student bodies in the country to one with almost no Black students, few Latinas/os, and few Asian Americans who were not of Chinese, Japanese, or Korean ancestry. ${ }^{8}$

II

Silence at Boalt Hall

\section{A. Summary}

Silence at Boalt Hall begins with the Civil Rights Movement of the 1960s. Guerrero recounts the gradual awakening of Boalt students, administrators, and faculty to the realization that the law school's student body was not adequately representative of the ever-diversifying population of California (pp. 1-5). She then describes the initial outreach efforts, or "soft" affirmative action, developed to counter the negative impact the traditional law school admissions process (LSAT- and GPA-based) had on students of color (pp. 5-7). When thcse efforts failed to achieve meaningful integration, Boalt Hall instituted "hard" affirmative action by creating a Special Admissions program in 1968 (pp. 10-11). From there, Guerrero moves on to describe the rapid diversification of Boalt's student body in the 1970s, the controversy this diversification engendered (the rest of Chapter 1), and conservatives' gradual resistance to and growing resentment of affirmative action in the 1980s (Chapter 2).

Guerrero then details the official dismantling of affirmative action by the Regents of the University of California ("U.C. Regents") 9 and the voters of California ${ }^{10}$ (Chapter 3). She also discusses the subsequent struggles

8. See generally Cheryl I. Harris, Critical Race Studies: An Introduction, 49 UCLA L. Rev. $1215,1224-25$ (2002) (discussing the impact of loss of diversity at UCLA).

9. In 1996, the U.C. Regents adopted SP-1, which ended the "use of race, religion, sex, color, ethnicity, or national origin as criteria for admission" in U.C. professional schools and graduate programs. Regents of the University of California, Resolution Special Policy l (July 20, 1995).

10. In 1997, California voters adopted the ballot measure Proposition 209, which banned state discrimination or preferential treatment "on the basis of race, sex, color, ethnicity, or national origin in 
of Boalt students to ameliorate the effects of these significant changes (Chapter 4). Guerrero herself was a student (and protestor) at Boalt during this period. Likely bccause of her own experiences and participation, Guerrero richly brings to life the frustration many students felt not only about affirmative action's dismantlement but also about the nonresponsiveness of the Boalt administration and faculty. Silence at Boalt Hall concludes with a wide-ranging discussion of how Boalt Hall specifically, and higher education more generally, has coped with some of the more recent attacks on affirmative action in places like Georgia, Texas, Florida, and Washington State (Chapter 5). In the last section of this chapter, Guerrero draws on the narratives of Boalt students, both White and non-White, to highlight their discomfort about the ways in which the lack of diversity at Boalt Hall has become both normative and normalized.

\section{B. Comments and Criticisms}

Guerrero's thirty-plus year history of affirmative action at Boalt is the most compelling aspect of Silence at Boalt Hall. Less successful, but still compelling, is her presentation both of the arguments for and against affirmative action in higher education and of the subtle ways in which race, racism, diversity, and politics impact the debate. While Guerrero describes her book as a story "nestled between" arguments of policy (p. xiii), the opposite is more accurate: nestled in the story are various policy debates regarding the benefits and drawbacks of race-consciousness in admissions and faculty hiring. The strength of this structural approach is that several key aspects of the affirmative action debate take on new meaning and significance when seen in the context of Boalt's affirmative action history. The drawback of this structure is an often disjointed presentation of important policy aspects of the debate and a failure to connect that debate to Boalt's post-affirmative action status.

Consider, for example, the question of whether affirmative action is still needed. Critics of affirmative action, at the most basic level, argue that even if affirmative action were once needed, it no longer is. The playing field is now level; or, as Ward Connerly puts it, it is time to take off the "'training wheels" (p. 71). In response, affirmative action proponents point to the precipitous drop in minority enrollment following affirmative action's dismantling to claim that the playing field is still tilted. They argue that, to the extent progress has occurred, that progress stems primarily from race-conscious programs. While Guerrero usefully situates these arguments vis-à-vis "resegregation"11 at schools such as Boalt and UCLA Law, she

the operation of public employment, public education, or public contracting." Proposition 209, codified at CAL. Const. art. $1, \S 31$.

11. The reference here is to the protests that UCLA students have mounted over the past few years against what they have called the "resegregation" of the law school. 
does not explicitly articulate the relevance of these arguments for postaffirmative action institutions.

Another concern is that Guerrero is not always as careful as she might be with respect to racial categorization. For example, she sometimes treats Asian Americans as a homogenous population, failing to distinguish adequately between different Asian ethnicities. While Guerrero does occasionally recognize that affirmative action affected Filipina/o students differently than Japanese students, her analysis sometimes fails to consider the significance of this difference, resulting in flawed conclusions. For instance, Guerrero argues that because the percentage of Asian American students enrolled at Boalt, UCLA Law, and U.C. Davis School of Law changed only negligibly after the repeal of affirmative action, the only true beneficiaries of Resolution SP-1 and Proposition 209 are White students (p. 171). However, since Filipina/o and Southeast Asian (such as Laotian and Cambodian) student enrollment dropped precipitously as a result of anti-affirmative action measures, the only way overall Asian American enrollment could remain the same is if other subcategories (such as Japanese, Chinese, and Korean) rose significantly with the repeal of affirmative action.

Finally, Silence at Boalt Hall does not advance our understanding of racial diversity. Like most participants in the affirmative action debate, Guerrero deploys the concept without articulating its meaning and functions. As Guerrero's book demonstrates, for the most part diversity factors into discussions about affirmative action in roughly the following manner: To opponents of affirmative action, diversity means quotas and "underqualified" people of color; to supporters, diversity means a richer learning environment and social progress. At best, these arguments are underdeveloped, which is surprising given the political and doctrinal currency of diversity in public and academic discussions on affirmative action.

Our project in the next section is to broaden the terms upon which diversity is discussed. We do so by identifying several important functions of diversity. Our discussion is admittedly a rough first cut at a complex question. Still, we hope that the taxonomy and conceptualization below will persuade people to take the diversity rationale for affirmative action more seriously.

III

\section{Conceptions of Racial Diversity}

This Part seeks to answer the title question of this Review Essay: What exactly is racial diversity? We define racial diversity both conceptually and functionally. Conceptually, racial diversity conveys the idea that a relationship exists between race and social experiences, on the one hand, and knowledge and practices, on the other. Central to racial 
diversity, then, is the notion that how we experience, think about, and conduct ourselves in society is shaped, though not determined, by our race. But this definition does not yet answer the question of why racial diversity is important. In other words, it fails to provide an indication of how racial diversity functions. This Part lays out seven functions of diversity: (1) inclusion; (2) social meaning; (3) citizenship; (4) belonging; (5) colorblindness; (6) speech; and (7) institutional culture. Each function derives from the relationship between race and social experiences.

Four caveats are in order. First, the functions we describe do not exhaust the impact racial diversity has in education and in society more broadly. Second, while the functions of diversity we identify are overlapping and interconnected, for heuristic purposes we articulate them separately. Third, though, for the most part, we explicate each conception with a law school context in mind (because that is the context with which we are most familiar), these conceptions have broader resonance. Finally, we do not fully explicate any of the conceptions we provide. We offer them as starting points.

\section{A. Inclusion}

Racial diversity has the potential to facilitate inclusion. Undergirding this function is the normative idea that the racial demographics of colleges and universities should approximate the racial demographics of society as a whole. Put another way, academic institutions should look at least somewhat like America. ${ }^{12}$ The diversity problem arises when this is not the case. For example, if School $\mathrm{X}$ is situated in a region with a Black population of $\mathrm{I} 2 \%$, that school is insufficiently diverse if Blacks make up significantly less than $12 \%$ of that school's student body. The strong version of this idea would require schools to structure their admissions around quotas. Weak versions require only that schools pay attention to societal racial demographics and use them as a benchmark against which to evaluate their own diversity.

Driving the inclusion function is a concern not just about demographics or representation, but about the very nature of American society. Universities and colleges define American democracy and serve as gateways to its benefits. To the extent that certain groups are excluded from universities and colleges, a democratic process failure has occurred. The mandate of diversity requires that all groups have access to a constitutive aspect of American democracy: a college education. No group should be left behind. 


\section{B. Social Meaning}

A second function of divcrsity is to disrupt negative social meanings-stereotypes-about race. To continue the earlier example, if Blacks are $12 \%$ of the population but only $4 \%$ of a college's entering class, people are likely to attribute social meaning to this differential. Some may conclude either that Blacks are intellectually inferior to Whites or do not work as hard. Of course, the argument is often made that affirmative action programs convey that very idea-that Blacks need affirmative action because they are intellectually inferior to Whites. However, Black/White student intellectual interactions can change White students' perceptions of Black intellcctual capacity. Conversely, the absence of Black students does little to disrupt, and likely entrcnches, extant stereotypes about Black intellectual inferiority.

\section{Racially Cooperative Citizenship}

A third function of diversity is to facilitate the formation of a racially coopcrative society. Central to this function is the idea that universities are sites for Americanization. They naturalize us. In other words, who we become as Americans is a function of who we are as students. ${ }^{13}$ The nexus between school socialization and citizenship has profound implications for race. In short, school segregation produces and legitimizes societal segregation. At the most basic level, students perform in society the racial interactions they learn and rehearse in school.

The mandate of diversity helps create diverse campuses, and diverse campuses help socialize students to respect and embrace differences. Part of what makes this socialization possible is that universities encourage collegiality. The institutionalization of this norm structures how students interact with each other. ${ }^{14}$ Though student interactions are not always collegial, the existence of the collegiality norm increases the likelihood that students will bridge racial divides and develop interracial trust and understanding. To remove diversity (or reduce it significantly) from the educational setting is to eliminate one of the primary institutional contexts for interracial communication and community building. Without racial diversity, students learn to normalize racial exclusivity, a normalization that

13. Justice Powell recognized as much in Bakke, noting that "it is not too much to say that the 'nation's future depends upon leaders trained through wide exposure' to the ideas and mores of students as diverse as this Nation of many peoples." 438 U.S. 265, 313 (1978).

14. Cynthia L. Estlund, Working Together: The Workplace, Civil Society, and the Law, 89 Geo. L.J. 1, 24 (2000) ("The research has yielded a broad consensus that intergroup contact 'will reduce prejudice ... when (a) there is equality of status among the individuals in contact, (b) they meet in a situation of cooperative interdependence, and (e) ... there is normative support for friendly intergroup relations."'); see also Devon W. Carbado \& Mitu Gulati, The Law and Economics of Critical Race Theory, 112 YALE L.J. (forthcoming June 2003). 
helps determine the kind of racial citizens they become and the kind of racial citizenship they tolerate.

\section{Belonging}

A fourth function of diversity is to promote belonging. To the extent that any racial group is underrepresented within a university, the students from that group may be perceived as outsiders: students who are not supposed to be there; students who do not belong. ${ }^{15}$ With greater diversity, the institutional message that each underrepresented student belongs is strengthened.

One might argue, however, that affirmative action and other diversity programs actually undermine students of color belonging. The notion might be that if, for example, a university does not have an affirmative action policy and admits a small number of Latinas/os, White students will perceive that these students really belong-that they are special. Deserving. They got in based on merit, not race. They are exceptions to the rule that Latinas/os cannot compete without affirmative action. We refer to this perception as "racial exceptionalism." 16

Assuming that the lack of diversity programs produces racial exceptionalism, it does not necessarily follow that racial exceptionalism produces belonging. As the experiences of UCLA law student Anthony Solana, Jr. attest, racial exceptionalism can engender racial conflict and alienation. According to Solana:

During my first year of law school I had the great fortune of doing well. However, I felt isolated because white students made so much about my ability to compete with them on equal footing ... I think people expected me not to do all that well. ... [A]fter I secured a job at a large law firm in Los Angeles, something that the majority of white students in my section could not do... I incurred their wrath. ${ }^{17}$

Implicit in Solana's narrative is the notion that, from his classmates' perspective, he was not supposed to do well, even though he was admitted to UCLA without affirmative action. More particularly, Solana was not supposed to do better than his White counterparts. Presumably, one reason Solana's classmates noticed his academic performance is that he was under

15. Cf. Kenneth L. Karst, Belonging to america: Equal Citizenship and the CONSTITUTION (1989) (employing the theme of belonging to analyze various aspects of American citizenship).

16. We are not the first to use this term. See, e.g., Sumi Cho \& Robert Westley, Critical Race Coalitions: Critical Movements that Performed the Theory, 33 U.C. DAvIS L. REv. 1377, 1423 n.94 (2000).

17. Brief of Amici Curiae UCLA School of Law Students of Color in Support of Respondent at 25-26, Grutter v. Bollinger, 288 F.3d 732 (6th Cir. 2002) (en banc), cert. granted, 123 S. Ct. 617 (Dec. 2, 2002) (No. 02-241), available at http://www.umich.edu/ urel/admissions/legal/gru_amicus-ussc/ um/BLSG-gru.pdf (last visited May 3, 2003). 
surveillance. His elassmates were watching him. Does he really belong? Is he really an exception? Can he really cut it? Racially invested students may want answers to the foregoing questions. But when the answer (as provided by grades) is not what they expect, their own sense of intellectual worth is compromised and racial antagonism of the sort Solana describes results. In sum, even if the absence of diversity programs produces racial exceptionalism, this exceptionalism will not necessarily promote belonging. By contrast, racial diversity likely does.

\section{E. Colorblindness}

A fifth function of diversity is to promote colorblindness. Though it may seem eounterintuitive, racial diversity promotes colorblindness by rendering the racial identities of non-White students less salient. The experiences of Jamaar M. Boyd, the only Black male student in Boalt's class of 2003, demonstrate the link between the lack of racial diversity and racial salience/consciousness. Boyd writes:

I entered Boalt Hall in the year 2000 as one of seven Black students. However, I was the only Black male. Prior to entering law school, I never defined myself by my gender in conjunction with my race. As a practicaI matter, however, I could not deny the reality of the situation: I was the only one. While there were other people within my class who shared my race, there was not one person who could assist me in providing my peers first hand insight into the Black male's perspective. This problem was compounded by the fact that I was the only Black student in all of my first-year classes. Thus, I was forced into the dual obligation of representing the perspective of the entire race within my classes while attempting to represent my own unique identity within the firstyear class.

It is still an open question on how this impacted me. However, it is clear that my classmates were cheated because they were denied a diversity of views from Black people who occupied varying socio-economic identities. By providing a range of views and experiences, there is a higher probability that the "Black perspective" is going to be expressed within the law school. Without this, people may be forced to attempt to gather the insight and experience of an entire race from one person. As the one Black male out of two hundred and seventy students that entered Boalt Hall in 2000 , I think that this is inherently unfair to the student, the student body, and the legal community as a whole. ${ }^{18}$

Boyd's narrative is significant in at least three respects. First, it highlights the burden of racial representation in academic contexts within which there is little or no racial diversity. Boyd felt pressured to speak for, and to 
represent, Black people. Second, Boyd's remarks reveal how this burden of representation is in tension with another-that he fit in. Boyd is in a racial double bind here: he is expected to fit in (assimilate) as a person and represent (differentiate) his race. Third, Boyd's comments suggest that the lack of racial diversity actually undermined his ability to be an individual. "Prior to entering law school, I never defined myself by my gender in conjunction with my race." ${ }^{\prime 19}$ The absence of diversity at Boalt Hall rendered Boyd racially salient. He became the racial embodiment of Every Blaek Man and thus was "forced" to define himself in racial terms. In sum, Boyd's experiences provide at least anecdotal evidence that the lack of racial diversity promotes, rather than discourages, racial identification, racial awareness, and racial consciousness. Far from undermining colorblindness, racial diversity promotes it.

\section{F. Speech}

A sixth set of functions of diversity involves speech. Diversity performs at least three important speech functions: (I) a content function; (2) a viewpoint function; and (3) a speaker identification function.

\section{The Content Function}

Racial diversity shapes the content of discussions, especially in educational settings. Underlying this claim is the idea that there is a relationship between identity and issue identification. Women, for example, may identify more with child care issues than men. Blacks, similarly, may identify more with racial issues than Whites. If aecepted, consider how this proposition might play out in the context of a criminal procedure elass, a course one of us teaches. Imagine the class is discussing Florida v. Bostick, ${ }^{20}$ a central case in criminal procedure. The facts of the case are as follows: While Bostick was sitting in the back of a bus, two law enforcement officers, both part of a drug interdiction effort, approached him and asked for identification, which Bostick provided. ${ }^{21}$ The officers then asked for permission to search Bostick's luggage, and the search yielded incriminating evidence. In court, Bostick moved to suppress the evidence on the grounds that he was unreasonably "seized" in violation of the Fourth Amendment. ${ }^{22}$ The Court hinted that it did not think Bostick was seized but remanded the case because the lower court had applied the wrong legal standard. ${ }^{23}$

19. Id. at 28 .

20. 501 U.S. 429 (1991).

21. Id. at 435 .

22. Id.

23. Id. 
Absent from the Court's analysis was an engagement of race and policing. The Court did not even mention that Bostick is Black. ${ }^{24}$ Thus, one could easily discuss this case without thinking about what many people consider a reality of American life-race-based policing. This omission is less likely if Black students are in the class. Black students are more likely to wonder whether Bostick is Black and whether race played a role in the officers' decision to engage him. To the extent that these issues are raised, the content of the classroom discussion will change. Among other issues, the class might discuss how, if at all, race should figure in the seizure analysis.

Under a content-based conception of diversity, the point is not that Black students would take a particular perspective on the role that race should play in the seizure analysis. The point is that the issue is more likely to be discussed with a Black presence in the classroom than without it. ${ }^{25} \mathrm{~A}$ vast body of social science literature demonstrates that communicative interactions among racially diverse groups are markedly different from communicative interactions between members of the same racial group. ${ }^{26} \mathrm{~A}$ "flavor" is lost in communications that do not contain the voices of people of color. ${ }^{27}$

\section{The Viewpoint Function}

The viewpoint function of diversity derives from a relationship between the identity of the speaker and what she is likely to say. People with different racial identities have different experiences and thus view the world differently. ${ }^{28}$ Different experiences and ideas help promote and

24. For a racial critique of Florida v. Bostick, see Devon W. Carbado, (E)racing the Fourth Amendment, 100 Mich. L. Rev. 946 (2002).

25. We draw from one of our personal experiences in teaching Bostick for this example.

26. See, e.g., Melanie Booth-Butterfield \& Felicia Jordan, Communication Adaptation Among Racially Homogenous and Heterogeneous Groups, 54 S. Сомм. J. 253 (1989).

27. Cf. Taylor v. Louisiana, 419 U.S. 522, 531-32 (1975) (stating that a community made up exclusively of one sex is different from a community composed of both sexes and that a distinct flavor is lost if either sex is excluded); see also Kimberlé Williams Crenshaw, Opening Remarks: Reclaiming Yesterday's Future, 47 UCLA L. REv. 1459, 1460 (2000). Crenshaw comments:

Our extemporaneous performances together always excited me and taught me to cherish the creative possibilities that working in a multiracial context provides. Yet, this delicate balance now is lost, and the music we make in our classrooms today is often flat and monotonous. When I step up to the podium today and pick up my baton, I see that my entire string section is gone-just gone-forget about playing anything that sounds remotely the way it should; the brass section is decimated, and the percussion can barely kick out a beat that can push us along. Surely I try to compensate by playing some of the missing instruments myself; 1'll jump in the string section to play a few measures, run over to the horns to blow a note or two, try to kick at the timpani on the way back to the podium, but there is no denying it-what we are creating in our classrooms today is simply subpar.

Id.

28. For a discussion of the complicated relationship between identity, politics, and perspective, see generally Devon W. Carbado, Race to the Bottom, 49 UCLA L. Rev. 1283 (2002) [hereinafter Carbado, Race to the Bottom]. 
sustain academic environments as robust marketplaces of ideasmarketplaces shaped by disagreement and debate. In an educational setting, disagreement and debate help remedy incorrect assumptions and generate new ideas. People with diverse backgrounds help facilitate such debate and shape the terms on which issues are discussed by drawing on their experienecs and contributing their unique viewpoints. ${ }^{29}$

For example, Justice Sandra Day O'Connor reeognized the relationship between experience, perspective, and debate in her tribute to the late Thurgood Marshall. ${ }^{30}$ There, she described the impact that Justice Marshall had upon her life-and her decisions. She recalled how, early in her legal career, Marshall's arguments in Brown v. Board of Education moved her:

[A]s I listened to Justice Marshall talk eloquently to the media about the social stigmas and lost opportunities suffered by African American children in state-imposed segregated schools, my awareness of race-based disparities deepened. I did not, could not, know it then, but the man who would, as a lawyer and jurist, captivate the nation would also, as colleague and friend, profoundly influence me. ${ }^{31}$

Justice O'Connor further reeognized that Justice Marshall's influence on her derived, at least in part, from the fact that they had "traveled [down] different $\operatorname{road}[\mathrm{s}],{ }^{, 32}$ that they had different identities, and thus different experiences. While, as a woman, she had "experienced gender discrimination enough," 33 she "had no personal sense... of being a minority in a society that cared primarily for the majority." 34 Though she did not always agree with Justice Marshall, after Marshall's departure from the Court she still found herself "looking expectantly for his raised brow and his twinkling eye, hoping to hear, just once more, another story that would, by and by, perhaps change the way I see the world." 35

Justice Thomas's recent participation in the oral arguments in Virginia v. Black ${ }^{36}$ also reveals how racial diversity can engender viewpoint-based speech. ${ }^{37}$ Justice Thomas, the only African American justice currently on

29. For an articulation of the evidence on the value of dissent and the harms of conformity, particularly in the educational setting, see Cass Sunstein, Conformity and Dissent (Pub. Law and Legal Theory, Working Paper No. 34, 2002), available at http://www.law.uchicago.cdu/academics/ publiclaw/resources/34.crs.conformity.pdf.

30. Sandra Day O'Connor, Thurgood Marshall: The Influence of a Raconteur, 44 STAN. L. REv. 1217 (1992).

31. Id.

32. Id. at 1219 .

33. Id.

34. Id. at 1217

35. Id. at 1220.

36. 123 S. Ct. $1536(2003)$.

37. See Joan Biskupic, Cross-Burning Case Agitates Thomas, USA Today, Dec. 12, 2002, at 3A; Jan Crawford Greenburg, Emotional Court Weighs Cross Burning: Thomas Speaks Against 'Terror', CHI. TriB., Dec. 12, 2002, at 10; Linda Greenhouse, An Intense Attack by Justice Thomas on Cross- 
the Court, interrupted the petitioner arguing in favor of Virginia's crossburning prohibition when the petitioner characterized cross-burning as a symbol that produced an impending fear for minorities. Justice Thomas contextualized the burning cross, linking it to its historical roots as a violent and terrorizing practice:

Justice Thomas: Mr. Dreeben, aren't you understating the-the effects of-of the burning cross? This statute was passed in what year?

Mr. Dreeben: 1952 originally.

Justice Thomas: Now, it's my understanding that we had almost 100 years of lynchings and activity in the South by the Knights of Camellia and-and the $\mathrm{Ku} \mathrm{Klux} \mathrm{Klan,} \mathrm{and} \mathrm{this} \mathrm{was} \mathrm{a} \mathrm{reign} \mathrm{of}$ terror and the cross was a symbol of that reign of terror. Wasisn't that significantly greater than intimidation or a threat?

Mr. Dreeben: Well, I think they're coextensive, Justice Thomas, because it is-

Justice Thomas: Well, my fear is, Mr. Dreeben, that you're actually understating the symbolism on - of and the effect of the cross, the burning cross. ${ }^{38}$

Presumably, Justice Thomas's identity as a Black person (and from a particular region and era) shapes his viewpoint about cross burning. And this viewpoint, articulated from a Justice known for his silence during oral argument, changed the normative terms upon which the oral argument proceeded ${ }^{39}$ After Justice Thomas's interruption, the constitutionality of cross burning could no longer be framed in terms of disgust or discomfort; the Court and the participants were forced to engage in a conversation about racial terror and violence. While we cannot know for sure what the nature of the conversation and questioning would have been without the presence of a Clarence Thomas, the transcript suggests that Justice Thomas's questions changed the substance and tone of the oral argument. ${ }^{40}$

\footnotetext{
Burning, N.Y. Times, Dec. 12, 2002, at A1; Shannon McCaffrey, Burning Crosses Symbolize Terror, Thomas Says; His Rare Comments Come as Supreme Court Weighs Whether Act Is Free Speech, ST. Louis Post-Dispatch, Dec. 12, 2002, at A2; Patty Reinert, Justices Debate Cross Burning: Virginia's Ban Violates Free Speech Rights, Challengers Argue, Hous. Chron., Dec. 12, 2002, at A5; David G. Savage, Thomas Assails Cross-Burning as Terror Tactic, L.A. TIMES, Dec. 12, 2002, at Al4.

38. United States Supreme Court Official Transcript, No. 01-1107, 2002 WL 31838589, at *2223 (Dec. 11, 2002) [hereinafter Transcript].

39. See Savage, supra note 37.

40. See, e.g., Transcript, supra note 38 , at $* 25$ (reporting the question of another Justice as beginning: "But it seems to me from this argument, if the message is as powerful as Justice Thomas suggests it is—and l'm sure he's-he's right about that ...").
} 


\section{The Speaker Identification Function}

In the context of discussions about important social policy questions, people pay attention not only to what is being said (viewpoint and content) but also to who is saying what. In other words, the identity of the speaker shapes how we respond to her arguments. Identity performs a signaling function for speech, and there are a number of different ways in which it can do so. ${ }^{41}$ The following hypothetical will help demonstrate this.

Imagine a criminal procedure class discussing Whren $v$. United States ${ }^{42}$ in which the Supreme Court held that racial profiling claims are not cognizable under the Fourth Amendment. A White student and a Latina student debate this decision in class. The White student supports the Court's opinion, and the Latina student does not. The class response to their arguments is likely to be shaped, at least in part, by how each student's identity cues her specch. Consider, for example, trustworthiness. The class could decide that they do not trust the White student's assessment of the harms of racial profiling because she has not been racially profiled. She is too removed, presuming to speak about a social problem she has not herself encountered. Alternatively, the class could decide that the Latina student is too situated, too emotional, too close to the experience, to perform a cost/benefit analysis objectively. However the class responds, it likely will take into account the cuing effect of each student's identity. ${ }^{43}$ This euing effect will inform how the class thinks about each student's ideas, not only with respect to trustworthiness, but also with respect to such important criteria for evaluating speech as persuasiveness, legitimacy, credibility, and authority.

\section{G. Institutional Culture}

A seventh function of diversity is that it engenders student initiative and involvement. Diversity can engender conduct with the potential to transform universities. Concretely, as a result of diversity, students have broadened the intellectual activity of universities and shaped their institutional cultures. For example, the presence of students of color and other

41. See Shelly Chalken, Heuristic Versus Systematic Information Processing and the Use of Source Versus Message Cues in Persuasion, 39 J. Personality \& Soc. Psychol. 752, 752 (1980) (suggesting that people rely on "non-content cues" including, but not limited to, "identity" in evaluating the message of the speaker). For a canvassing of this literature that suggests that in processing speech, listeners pay attention to both content- and noncontent-based cues, see Gia B. Lee, Persuasion, Transparency, and Government Speech (2002) (unpublished manuscript, on file with authors).

42. 517 U.S. 806 (1996).

43. One could complicate identity issues further by adding details about each speaker's dress, mannerisms, hair, or other performative aspects of identity. For an argument about how race is understood not only in terms of phenotypic evidence (for example, whether a person is Asian American) but by performative evidence as well (for example, whether the person appears to be assimilationist or nonassimilationist), see generally Devon W. Carbado and Mitu Gulati, Working Identity, 85 CORNELL L. REv. 1259 (2000). 
disadvantaged groups has affected both undergraduate and law school curricula. Not until large numbers of minorities were admitted to colleges and universities in the late 1960s did those institutions begin to develop Black Studies programs and departments devoted to ethnic studies. Chicana/o studies programs were also dcveloped largely in response to student demands in West Coast public universities. ${ }^{44}$ In 1969, students of color at U.C. Berkeley led the Third World Strikc, which Sumi Cho and Robert Wcstley describe as one of "the most institutionally significant student strike[s] in U.C. Berkeley's history." ${ }^{25}$ This strike triggered the creation of the Ethnic Studies departments and affirmative action admissions and recruitmcnt at U.C. Berkeley, a historically White educational institution. ${ }^{46}$

Student-body diversity has likewise shaped legal education and scholarship. The dcvelopment of Critical Race Thcory, for example, is directly linked to the presence and activism of students of color at Harvard Law School and Boalt Hall, among other institutions. ${ }^{47}$ As a result of this continuing presence and activism, almost every law school offers at least one course focusing directly on race and the law, and scveral have a course specifically titled Critical Racc Thcory. Quite recently, Asian American students at Columbia Law School persuaded the administration to add an Asian American Jurisprudence course to the curriculum. At UCLA, the law school faculty approved a Critical Race Studies Curriculum, which offers students the opportunity to engage in a systematic and rigorous cxamination of the ways in which law, historically, has both created and restricted the social, economic, and political opportunities of people of color. None of the foregoing developments would have occurred without students of color.

For the most part, the foregoing conceptions of diversity are absent from the affirmative action literature. This is a problem because, as Guerrero points out, diversity is the most palatable justification for affirmative action. To put the point another way, supporting diversity in education is less controversial than challenging institutional racism in education. In this respect, it bears mentioning that the diversity rationale for affirmative action leaves in place traditional admissions criteria, like LSAT scores,

44. See Jean Stefanic, Latino and Latina Critical Theory: An Annotated Bibliography, 85 CALIF. L. REV. 1509, 1510 (1997).

45. See Cho \& Westley, supra note 16 , at 1382.

46. Id. at 1382 .

47. See Critical Race Theory: The Key Writings that Formed the Movement xiv, xix (Kimberlé Crenshaw et al. eds., 1995); MARI J. Matsuda, Where Is Your Body? ANd OTHER ESSAYS ON RACE, GENDER, AND THE LAW 50 (1996); Cho \& Westley, supra note 16, at 1378-79, 1404; see also Peter M. Cicehino, An Activist at Harvard Law School, 50 AM. U. L. REv. 551,555 (2001) (discussing how gay and lesbian student protest helped establish courses that focus on issues germane to the gay and lesbian community). 
which embed race and class preferences ${ }^{48}$ And, indeed, few of the briefs in the Michigan cases before the Court contest the legitimacy of standardized tests, even though the racial effects of these tests are stark. ${ }^{49}$

But neither do these briefs set out precisely how racial diversity functions. That was the goal of this Review Essay: to begin a conversation about the contours of racial diversity and to move the academic and jurisprudential discourse about diversity away from the question of whether, for example, Blacks speak in a "different voice" 50 to the question of whether the absence of Black people speaking on college and university campuses undermines American democracy.

\section{CONCLUSION}

The functions of racial diversity we describe in this Review Essay can be employed as a set of criteria for determining what kinds of diversity universities should pursue. Consider what these criteria suggest vis-à-vis the claim that there is an inadequate representation of White, fundamentalist Christians in law school student populations. On its face this is a racial diversity argument. But does this racial diversity argument have the same force as ours? Recall that diversity helps to undermine negative social meanings about race. What would be the social meaning value of increasing the representation of White, fundamentalist Christians in the law school's student body? Asked a little differently, is there a danger that the underrepresentation of White, fundamentalist Christians will entrench, legitimize, or reproduce a set of preexisting negative stereotypes of White, fundamentalist Christians? Consider now the function of inclusion. Is there an underrepresentation of White, fundamentalist Christians in the democratic process such that there is a particular need to provide them with access to educational capital or place them in positions of economic privilege? If the answer to these questions is in the negative, then one can query whether the inclusion of White, fundamentalist Christians is as compelling as the inclusion of Latinas/os from South Central Los Angeles.

Significantly, our claim is not that the functions of diversity we describe should operate as a set of criteria in a once-and-for-all sense. Race is a social construction, shifting in meaning over time and from context to context. In some contexts, the inclusion of a White, fundamentalist

48. See generally Luke Charles Harris \& Uma Narayan, Affirmative Action and the Myth of Preferential Treatment: A Transformative Critique of the Affirmative Action Debate, 11 Harv. BLACKLetTER L.J. 1 (1994).

49. But see Brief of Amici Curiae on Behalf of a Committee of Concerned Black Law Graduates in Support of Respondents, Grutter v. Bollinger, 288 F.3d 732 (6th Cir. 2002) (en banc), cert. granted, 123 S. Ct. 617 (Dec. 2, 2002) (No. 02-241), available at http://www.umich.edu/ urel/admissions/legal/ gru_amicus-ussc/um/BLSG-gru.pdf (last visited May 3, 2003).

50. See Carbado, Race to the Bottom, supra note 28, at 1297-1305 (complicating the relationship between identity and voice). 
Christian will add more diversity than the inclusion of a Latina/o from Los Angeles. Our claim instead, then, is that once we have a set of criteria, we can move to debating whether the criteria are appropriate and whether the particular kind of diversity being pursued adequately satisfies those criteria. We hope that the taxonomy of diversity functions we provide moves the literature and the political conversations surrounding diversity in this direction. 